http://zakon4.rada.gov.ua/laws/show/75/98-вр. - Назва 3 екрану. 2. Криворізький державний педагогічний університет: Moodle [Електронний ресурс]. - Режим доступу: http://kdpu.edu.ua/Moodle/. - Назва 3 екрану. 3. Наказ МОН України «Про затвердження Положення про дистанційне навчання» від 25 квітня 2013 р. № 466 [Електронний ресурс]. Режим доступу : http://zakon1.rada.gov.ua/laws/show/ z0703-13. - Назва з екрану. 4. Наказ МОН України «Про затвердження Положення про електронні освітні ресурси» від 01 жовтня 2012 р. № 1060 [Електронний ресурс]. - Режим доступу: http://zakon4.rada.gov.ua/laws/show/z1695-12. Назва 3 екрану. 5. Томіліна А. О. Організація контрольно-оцінювальних дій із залученням системи Moodle для студентів гуманітарних спеціальностей / А. О. Томіліна // Теорія й методика електронного навчання. - Кривий Ріг : НМетАУ, 2012. - Вип. 3. - С. 293-298. 6. Томіліна А. О. Освітній потенціал інформаційних технологій в освітньому просторі / А. О. Томіліна // Інноваційні інформаційно-комунікаційні технології навчання математики, фізики, інформатики у середніх та вищих навчальних закладах: всеукр. наук.-метод. конф. молодих науковців, 17-18 лют. 2011 р.: [тези доп.]. - Кривий Ріг : Криворіз. держ. пед. ун-т, 2011. - Вип. 1. - С. 392-395.

УДК 65.011.46

Галина Уткіна

\title{
ІНТЕЛЕКТУАЛЬНА АКТИВНІСТЬ ЯК ОСНОВА ІННОВАЦІЙНОЇ АКТИВНОСТІ
}

Уткіна Г. А. Інтелектуальна активність як основа інноваційної активності.

У статті обгрунтовано зв’язок між людським фактором та виробничим фактором управління знаннями, тобто між інтелектуальною активністю та інноваційною. Визначено три впорядковані компоненти навчального процесу та їх взаємодію: джерело знань; джерело поглинання знань (студент); практичне відтворення знань. Обгрунтовано синергетичне походження знань організації.

Ключові слова: інтелектуальна активність, інновація, інноваційна активність, синергетика, знаннєва економіка.

Уткіна Г. А. Интеллектуальная активность как основа инновационной активности.

В статье обосновывается связь между человеческим фактором и производственным фактором управления знаниями, то есть между интеллектуальной активностью и инновационной активностью. В статье определены три упорядоченных компонента учебного процесса и их взаимодействие: источник знаний; источник поглощения знаний (студент); практическое воспроизведение знаний. Обосновано синергетическое происхождение знаний организации.

Ключевые слова: интеллектуальная активность, инновация, инновационная активность, синергетика, экономика знаний.

Utkina G. A. Intellectual activity as a basis of innovative activity.

In the article the relationship between the human factor and production factor knowledge management, or between intellectual activity and innovation activity. The article defines three of the ordered components of the educational process and their interactions: power knowledge; power absorption of knowledge (student); playing practical knowledge. The origin of knowledge is knowledge synergistic organization. 
Key words: intellectual activity, innovation, innovative activity, synergy, Knowledge Economy.

Новий Закон України «Про вищу освіту» так виокремлює основний вектор функціонування системи вищої освіти: це поєднання освіти з наукою та виробництвом задля підготовки конкурентоспроможного людського капіталу для високотехнологічного та інноваційного розвитку країни, самореалізації особистості, забезпечення потреб суспільства, ринку праці та держави у кваліфікованих фахівцях. Структуру діяльності викладацького складу вищої школи з майбутніми фахівцями визначено в такий спосіб: одним з основних завдань навчального закладу є забезпечення органічного поєднання в освітньому процесі освітньої, наукової та інноваційної діяльності [8, р. 6 ст. 26], а далі: наукова, науковотехнічна та інноваційна діяльність у вищих навчальних закладах є невід'ємною складовою освітньої діяльності і проводиться 3 метою інтеграції наукової, освітньої і виробничої діяльності в системі вищої освіти. При цьому зазначається, що основним завданням $є$ застосування нових наукових, науково-технічних знань під час підготовки фахівців з вищою освітою [8, р. 11 ст. 65].

Як відомо, навчальний процес визначається трьома впорядкованими компонентами: джерело знань; джерело поглинання знань (студент); практичне відтворення знань. Спільною вимогою до всіх цих компонентів є «бути якісним відповідно до змісту діяльності». Саме це і повинно гарантувати доцільність модернізації вищої освіти, задаючи вектор переходу від людського фактору до виробничого. А це обумовлює необхідність з’ясування сенсу такого зв'язку як наукової основи реального поєднання в освітньому процесі освіти та інноваційної діяльності.

Метою статті є обгрунтування функціонального зв’язку між людським фактором та виробничим фактором управління знаннями - інтелектуальною активністю та інноваційною активністю.

У джерелах з питань наукового обгрунтування проблем інноваційної діяльності поширеним $є$ використання економічної категорії «інноваційна активність» як міри такої діяльності. Це обгрунтовується в цілій низці досліджень. 3-поміж них праці іноземних та вітчизняних науковців І. Ансоффа, Д. Моррісона, К. Крістенсена, Ф. Янсена, І. Баранової, М. Черепанової,В.Баранчеева, Р. Фатхутдінова, І. Тарасенко, О. Королько, К. Белявської, Л. Федулової, І. Федулової. При цьому найчастіше в наукових джерелах ключовими поняттями, як родовими для поняття «інноваційна активність», є поняття «комплексна характеристика інноваційної діяльності» 2 ; $3 ; 1 ; 15]$ без деталізації тлумачення сенсу такого поняття, «діяльність» (в явному чи неявному виді) [12; 10; 9; 13] та ототожнення цієї категорії з окремими характеристиками інноваційної діяльності, таких як, ефективність, регулярність, готовність, інтенсивність, спрямованість [14; 7; 5; 16; 13$]$.

Намагаючись розкрити сутність категорії «інноваційна активність», найчастіше увагу спочатку зосереджують на показниках інноваційної діяльності, на котрі впливає ця категорія, а потім виокремлюють ті показники, зміст яких, на думку авторів, може бути мірою інноваційної діяльності. Ці два джерела інформації (родове поняття та відібрані характеристики) стають основою опису категорії «інноваційна активність», який ніяк не може бути його означенням, бо означення об’єкта вивчення (як джерела певної інформації) будується за певними правилами і має певне функціональне призначення, а саме: або розкриває зміст терміна, або вводить новий термін для позначення нового об'єкта дослідження. Найчастіше структурно означення є введенням інформації через найближче 
родове поняття і видову відміну, або через опис походження об’єкта дослідження (генетично).

Існуючі підходи до вибору найближчого родового поняття для категорії «інноваційна активність» ускладнюють ії використання на практиці як засобу оцінки реалізації інноваційної діяльності та відшукання шляхів прискорення, удосконалення інноваційного процесу, що, як відомо, важливо в межах конкурентної економіки.

Для того щоб визначитися щодо змісту категорії «інноваційна активність організації», необхідно виокремити сенс поняття «активність діяльності». На нашу думку, це поняття доречно трактувати як специфічний характер реалізації конкретної діяльності суб'єкта по відношенню до певного суб’єкта або об’єкта. Тобто це поняття має смисл лише у словосполученні з іншим поняттям (явному чи неявному): активність (чогось) - активність діяльності. Ураховуючи те, що діяльність буває різних видів, уточнюється: «активність якої діяльності? - активність інноваційної діяльності. Оскільки зв'язок іменників «активність» і «діяльність» $\epsilon$ постійним, то на практиці отримане словосполучення заміняють словосполученням «інноваційна активність». Так з'ясовується найближче родове поняття для поняття «інноваційна діяльність» - це діяльність, а воно стає генетичною основою для поняття «активність інноваційної діяльності» як результат синергетичного об’єднання двох функціональних сенсів поняття «діяльність»:

- на що спрямована діяльність організації - на реалізацію інновації;

- який характер має реалізація інноваційної діяльності - активний (неактивний).

На практиці сутність категорії «активність інноваційної діяльності» представляється словосполученням «інноваційна активність», а не словосполученням «інноваційність активності». Отже, маємо категорію «інноваційна активність організації»- це її активність інноваційної діяльності, яка відтворює характер реалізації діяльності організації під час інноваційного процесу.

Розгляд економічних категорій на засадах знаннєвої економіки (економіки, що базується на знаннях) обумовлює необхідність здійснення перегляду раніше сформованого змісту цілої низки категорій. Враховуючи це, закономірним буде в основу формування сенсу категорії «інноваційна активність організації» покласти ті критерії, які, будучи пов’язані 3 інноваційною діяльністю, відтворюють основні особливості такої економіки. А таким, передусім є синергетичне походження знань організації.

Синергетичне бачення світу - це вміння вбачати в сьогоднішньому стані нелінійної системи ті фрагменти, у яких процеси, що мають місце нині, відбуваються так, як вони відбувалися в будь-якій системі в минулому, і ті фрагменти, у яких процеси відбуваються так, як вони будуть відбуватися в будь-якій системі в майбутньому. При цьому, це елементи готового нереконструктованого минулого і реального немодельованого майбутнього [11].

Ми обгрунтовали синергетичне походження знань організації. Ці знання, будучи породженими індивідуальними знаннями персоналу організації та за рахунок інформаційних потоків, не є лінійно залежними від сукупності знань персоналу. Взявши за основу психологію інтелекту, з'ясували сутність психологічної категорії «інтелектуальна активність особи», а саме: згідно 3 теорією Д. Богоявленської [4] - це інтегральна властивість (характеристика) деякої системи, основними компонентами якої $\epsilon$ інтелектуальні компоненти і деякі не інтелектуальні (передовсім, мотиваційні).

Трансформувавши такий підхід щодо людського капіталу організації, де під трансформацією в економіці розуміють зміну цілей напрямку діяльності, обгрунтували 
сутність поняття «інтелектуальна активність організації» 3 урахуванням синергетичного походження інтелекту організації та специфіки мотивів виробничої діяльності на засадах знаннєвої економіки. Так виокремились дві діяльності - інтелектуальна й інноваційна та відповідні активності. Ці дві категорії часто зустрічаються в наукових джерелах, але не йдеться про зв'язок між ними.

На нашу думку, органічний зв’язок сутності цих понять («інтелектуальна активність», «інноваційна активність») зумовлює зв'язок понять «інтелект» і «інновація» та видів виробничої діяльності - «інтелектуальна діяльність» й «інноваційна діяльність». Оскільки базою для здійснення інноваційної діяльності $є$ знаннєва економіка, то для наповнення змістом категорії «інноваційна активність» закономірно взяти специфічні властивості тієї організації, у якій формується знаннєвий підхід до виробничої діяльності, а з опорою на практику оцінити зв’язки понять «інтелект організації» й «інноваційна діяльність». Ураховуючи це, при обгрунтуванні системного забезпечення функціонування переходу організації в статус «інтелектуальна організація», нами було виокремлено три основні вектори такої діяльності, а саме:

I вектор - інтелектуальна активність організації:

- інтелект особи, інтелект базового людського капіталу $\Rightarrow$ інтелект людського потенціалу організації при переході до інноваційної діяльності;

- навчання знань організації як інноваціі $\Rightarrow$ інтелект організації;

- індивідуальні мотиви, кодекс мотивів виробничої діяльності $\Rightarrow$ погодження мотивів;

- інтегральне об’єднання інтелекту і погоджених мотивів $\Rightarrow$ інтелектуальна активність людського потенціалу організації при переході на інноваційну діяльність;

II вектор - створення середовища для забезпечення неперервного навчання персоналу:

- загальноосвітні знання, спеціальна освіта;

- навчання знань організації (навчення різних рівнів персоналу на початку формування знань організації);

- системне і систематичне поповнення знань організації за рахунок інформаційних потоків різної форми реалізації;

- система заохочення;

- наскрізний контролінг;

III вектор - забезпечення інноваційною технологією (інноваційна технологія):

- бачення організації на основі діагностики та стратегічного планування $\Rightarrow$ місія організації;

- наявність відповідної технології та технічної бази для інноваційного процесу.

3 урахуванням виокремлених векторів формування організації на засадах знаннєвої економіки 3'явилась можливість виокремити такий набір характеристик інноваційної діяльності, котрі $є$ достатніми і необхідними для розкриття сутності категорії «інноваційна активність». На нашу думку, інноваційна активність організації (активність інноваційної діяльності) - це система характеристик реалізації інноваційної діяльності 3 побудови організації на основі максимального використання інтелектуальної активності людського капіталу організації за умови забезпечення відповідного середовища здійснення неперервного навчання персоналу знань організації та наявність інноваційної технології відповідно до змісту контексту організації задля посилення її конкурентоспроможності.

Усі виокремленні вектори з формування інтелектуальної організації та їх наповнення синергетично взаємопов’язані й обумовлені. Тріада «інтелектуальна активність»; 
«середовище для навчання»; «інноваційна технологія» як синергетичний об’єкт представлена схемою «Синергетична тріада категорії «інноваційна активність»» (рис. 1), де інтелектуальна активність організації є мірою її інноваційності, оскільки саме вона характеризує основний параметр категорії «інноваційна активність». Інноваційна технологія визначає тип категорії відносно конкретного змісту інновації (специфіку інноваційного процесу), а середовище для навчання визначає ієрархічність підсистем для складної системи неперевного створення умов поповнення новими знаннями колективу організації.

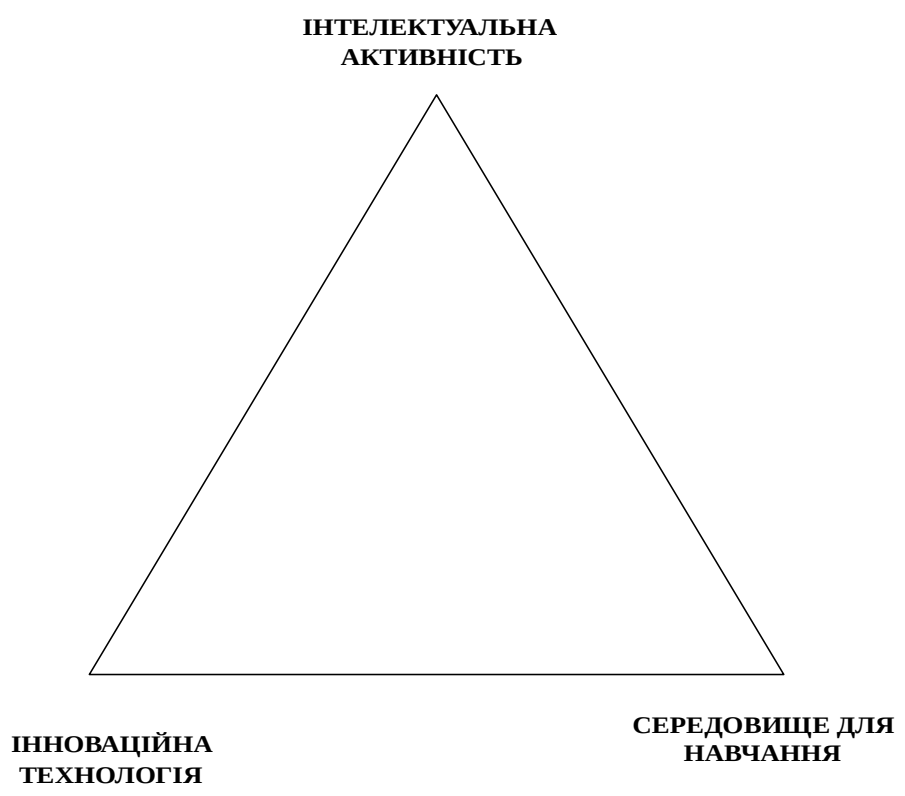

Рис. 1. Синергетична тріада категорії «інноваційна активність»

Вище запропоноване наповнення сутності категорії «інноваційна активність» на засадах знаннєвої економіки закономірно передбачає потребу мати математично обгрунтовану модель для аналізу стану організації з погляду оцінки інноваційної активності організації. Розглядаючи тріаду «інтелектуальна активність»; «середовище для навчання»; «інноваційна технологія» як складну відкриту нестійку систему синергетичного походження, можемо обгрунтувати одну з її моделей, використовуючи сенс математичного змісту операції «векторний добуток множин». Така модель дає можливість задати одну 3 нелінійних залежностей вщткремлених вище векторів.

Нехай $\boldsymbol{Q}$ - інтелектуальна активність організації, $\boldsymbol{b}$ - середорище плля навчання, $\boldsymbol{C}$ інноваційна технологія. Елементи сукупності векторів $\underset{a}{a}, \vec{b}, \underset{c}{,}$, як інтегральні характеристики інноваційної діяльності організації, обчислюються окремо за певною спеціальною методикою і нормуються за принципом індексації. Це надає можливість так виокремлені вектори помістити в деякий координатний квадрант тривимірного простору, а потім ңа рqнові означення операції «векторний добуток», знайти векторний добуток ( $\boldsymbol{a}_{\mathrm{x}} \boldsymbol{b}$ )х $\boldsymbol{C}$, якийпрннципово може бути представлений двома етапами:

I етап - $\left(\boldsymbol{a}_{\mathrm{x}} \boldsymbol{b}\right)=t-$ знання організації як результат навчання в середовищі, створеному організацієр,

II етап - $(t \times c)=d-$ інноваційна активність організації, породжена вже 
сформованими знаннями організації відповідно до інноваційної технології.

Використовуючи таким чином синергетичне походження знань організації, отримали можливість трансформації сутності категорії «інтелектуальної активність» в сутність категорії «інноваційної активності організації» і обгрунтувати можливість урахування взаємовпливу основних синергетичних факторів інтелектуальної організації на ії̈ інноваційну активність. Як результат отримали можливість визначитися щодо сутності категорії «інноваційна активність організації» на засадах економіки, що побудована на знаннях, на основі залучення основних векторів інноваційної діяльності як необхідних і достатніх умов для оцінки такої діяльності

Отже, запропонована нами математична модель функціонального зв’язку категорій «інтелектуальна активність» та «інноваційна активність» надає можливість на практиці прогнозувати основні шляхи розвитку інтелектуальної активності кожного фахівця та використовувати їі для формування інноваційних навичок та вмінь молодого спеціаліста.

\section{Література}

1. Балашов А. И. Инновационная активность российских предприятий: проблемы измерения и условия роста / А. И. Балашов, Е. М. Рогова, Е. А. Ткаченко. - СанктПетербург : Изд-во СПбГПУ, 2010. - 205 с. 2. Баранова И. В. Методические подходы к оценке инновационной активности и инновационного потенциала вуза [Электронный ресурс] / И. В. Баранова. - Режим доступа: htip://novinkor.com/ bibliotekainnoworld/71innoactive.himl 3. Баранчеев В. П. Управление инновациями: [учебн.] / В. П. Баранчеев, Н. П. Масленникова, В. М. Мишин. [5-е изд.] - Москва : ИД Юрайт, 2011. - 711 с. 4. Богоявленская Д. Б. Пути к творчеству / Д. Б. Богоявленская. - Москва : Знание, 1981. 96 с. 5. Валеева Е. О. Роль инновационной активности в осуществлении инновационной деятельности туристской фирмы / Е. О. Валеева // Актуальные проблемы экономики и новые технологии преподавания (Смирновские чтения) материалы IV Междунар. научн.-практ. конф., 16-18 апр. 2005 г. - Санкт-Петербург : Изд-во Международного банковского института, 2005. - С. 25-31. 6. Википедия - свободная общедоступная многоязычная универсальная интернет-энциклопедия [Электронный ресурс]. 7. Гильярди Ю. А. Управление инновационной деятельностью предпринимательских структур в рыночной среде : автореф. дисс. на соискание ученой степени канд. экон. наук : спец. 08.00.04 «Економика и управление предприятиями» / Ю. А. Гильярди. - Великий Новгород, 2009. - 24 с. 8. Закон України «Про вищу освіту» № 1556-VII // Голос України. - 2014. № 148. 9. Зорин В. Е. Евразийская мудрость от А до Я: толковый словарь [Электронный peсурс] / В. Е. Зорин. - Режим доступа : http: //www.terme.ru/dictionary/470 10. Касьян 3. Е. Аналіз та формування складових інноваційної активності підприємств легкої промисловості / 3. Е. Касьян // Вісник КНУТД. - 2012. - № 2. - С. 168-172. 11. Князева Е. Н. Основные принципы синергетического мировозрения / Е. Н. Князева, С. П. Курдюмов. - Режим доступа : http://spkurdyumov.ru/philosophy/osnovnye-principy-sinergeticheskogo-mirovozreniya

12. Мельников О. Н. Инновационная активность как фактор повышения конкурентоспособности предприятия / О. Н. Мельников, В. Н. Шувалов // Российское предпринимательство. - 2005. - № 9 (69). - С. 100-104. 13. Економічна енциклопедія: у 3 т. / С. В. Мочерний, Б. Г. Гаврилишин, О. А. Устенко. - Київ : Академія, 2002. - Т. 3. - 952 с. 14. Нечепуренко М. Н. Организационно-экономический механизм управления устойчивым развитием предприятия на основе инновационной активности: автореф. дисс. на соискание ученой степени докт. экон. наук : спец. 08.00.04 «Економика и управление предприятиями» / M. Н. Нечепуренко. - Москва, 2007. - 41 с. 15. Никитина О. В. Методы оценки 
инновационной активности промышленных предприятий : автореф. на соискание ученой степени дисс. канд. экон. наук : спец. 08.00.05 «Розвитие продуктивных сил и региональная экономика» / О.В.Никитина. - Санкт-Петербург, 2007. - 24 с. 16. Словарь инновационных терминов [Электронный ресурс]. - Режим доступа: infosystems.ru/ library/slovar_ais_ 12l8/slovar_innovaci_l222.html. 17. Тарасенко I. O. Оцінка інноваційної активності підприємства в системі стратегічного управління / I. О. Тарасенко, О. М. Королько, К. С. Белявська // Актуальні проблеми економіки. - 2009. - № 9 (99). - С. 133-141.

УДК 378:37.01

Наталія Шульга

\section{ПОБУДОВА МОДЕЛІ ТРИ-СУБ’ЄКТНИХ ВІДНОСИН В ОСВІТНЬОМУ ПРОЦЕСІ ВНЗ}

Шульга Н. В. Побудова моделі три-суб’єктних відносин в освітньому процесі ВНЗ.

У статті побудовано модель три-суб’єктних відносин в освітньому процесі та охарактеризовано ії складники: суб’єкта, що навчає, суб’єкта, що навчається та суб’єкта, що визначає інформаційно-комунікаційне педагогічне середовище (IKПC). Як основні складники характеристик суб’єкта, який навчає та суб’єкта, який навчається виокремлено операційний, світоглядний та рефлексивний компоненти. Структуру ІКПС охарактеризовано за принципами побудови, особливостями організації та формами взаємодії елементів.

Ключові слова: система навчання, три-суб’єктна дидактика, модель освітнього процесу, суб’єктність, навчальне середовище.

Шульга Н. В. Построение модели три-субъектных отношений в образовательном процессе вуза.

В статье построена модель три-субъектных отношений в образовательном процессе и охарактеризованы ее составляющие: обучающий субъект, обучающийся субъект, субъект, определяющий информационно-коммуникационную педагогическую среду (ИКПС). В качестве основных составляющих характеристик обучающего и обучающегося субъектов, выделены операционная, мировоззренческая и рефлексивная компоненты. Структура ИКПС охарактеризована по принципам построения, особенностями организации и формам взаимодействия элементов.

Ключевые слова: система обучения, три-субъектная дидактика, модель образовательного процесса, субъектность, учебная среда.

Shulga N. V. The model of three-subject relations in the educational process of the university.

The model of three-subject relations in the educational process is represented in the article. Its components: the teaching subject, the learning subject and the subject that determines the information and communication learning environment (ICLE) have been characterized. The main characteristics of teaching and learning subjects are operating, worldview and reflective components. ICLE structure is defined according to the communication strategy, organization features and forms of elements interaction.

Key words: education, three-subject didactics, a model of the educational process, subjectivity, learning environment. 